\title{
STUDIEN
}

\section{ÜBER DIE ZELLE.}

\author{
VON \\ R. ALTMANN.
}

ERSTES HEFT.

MIT EINER TAFEL.

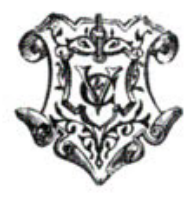

LEIPZIG,

VERLAG VON VEIT \& COMP.

I 886. 
